\title{
FAKTOR YANG MEMPENGARUHI NILAI PERUSAHAAN PADA PERUSAHAAN MANUFAKTUR SEKTOR CONSUMER GOODS
}

\author{
Kevin Petersen dan Kartika Nuringsih
}

Program Studi Manajemen Fakultas Ekonomi dan Bisnis Universitas Tarumanagara, Jakarta E-mail: Kevin.115160271@ stu.untar.ac.id

\begin{abstract}
Abstrak: Tujuan penelitian ini adalah untuk mengetahui dan menganalisis pengaruh leverage, business risk, firm size, kebijakan dividen, dan profitabilitas terhadap nilai perusahaan manufaktur sektor consumer goods yang terdaftar di Bursa Efek Indonesia periode 2016-2019. Sampel penelitian ini adalah sebanyak 18 sampel yang dipilih melalui metode purposive sampling. Data perusahaan untuk pemilihan sampel diambil dari website resmi Bursa Efek Indonesia, yaitu www.idx.co.id dan www.idnfinacials.com. Pengolahan data dilakukan dengan menggunakan software Eviews 10. Hasil penelitian ini menunjukkan bahwa leverage dan firm size memiliki pengaruh yang negatif dan signifikan terhadap nilai perusahaan. Profitabilitas memiliki pengaruh yang positif dan signifikan terhadap nilai perusahaan. Sedangkan, business risk dan kebijakan dividen tidak memiliki pengaruh yang signifikan terhadap nilai perusahaan.
\end{abstract}

Kata Kunci: Nilai Perusahaan, Leverage, Business Risk, Firm Size, Kebijakan Dividen.

Abstract: The purpose of this study is to determine and analyzing the effect of leverage, business risk, firm size, dividend policy, and profitability on firm value in manufacturing companies consumer goods sector listed on Indonesia Stock Exchange in 2016-2019 period. Number of samples are 18 samples by purposive sampling method. Data were collected through Indonesia Stock Exchange official website, which are www.idx.co.id and www.idnfinancials.com. Data were processed by using Eviews 10 software. The results in this study show that leverage and firm size have a negative and significant effect on firm value. Profitability has a positive and significant effect on firm value. While, business risk and dividend policy have no significant effect on firm value.

Keywords: Firm Value, Leverage, Business Risk, Firm Size, Dividend Policy.

\section{LATAR BELAKANG}

Perusahaan didirikan dengan tujuan utama untuk meningkatkan nilai perusahaan dan menyejahterakan para investor serta memaksimalkan laba perusahaan. Menurut Keown (2004) nilai perusahaan merupakan nilai pasar atas surat berharga utang dan ekuitas perusahaan yang beredar. Nilai perusahaan dapat diukur menggunakan beberapa aspek, salah satunya adalah Price to Book Value (PBV). Rasio Price to Book Value merupakan perhitungan dengan cara membandingan nilai saham menurut pasar dengan nilai buku ekuitas perusahaan. Semakin tinggi harga saham maka semakin banyak perusahaan yang berhasil menciptakan nilai bagi para pemegang saham (Purwohandoko, 2017). Untuk meningkatkan nilai perusahaan dibutuhkan faktor-faktor yang dapat mempengaruhi nilai perusahaan sehingga nilai perusahaan tersebut dapat meningkat. Faktor-faktor tersebut meliputi utang (leverage) yang merupakan salah satu cara untuk memperoleh modal sehingga dapat meningkatkan keuntungan perusahaan. Akan tetapi, utang yang terlalu banyak dapat menyebabkan penurunan laba sehingga perusahaan dianggap tidak sehat (Sari dan Abundanti, 2014). Leverage sendiri merupakan kebijakan yang dilakukan perusahaan dalam mendanai investasi perusahaan. 
Selain memberikan dampak baik, leverage juga dapat meberikan dampak buruk seperti meningkatkan business risk dikarenakan bunga yang terus meningkat akibat besarnya utang sehingga perusahaan tersebut akan mengalami kebangkrutan karena tidak dapat membiayai biaya operasi perusahaan tersebut. Oleh karena itu, sebelum melakukan penggunaan utang lebih baik dipikirkan terlebih dahulu mengenai dampak yang akan diberikan. Nilai perusahaan juga dapat dipengaruhi oleh faktor lainnya, seperti Firm size karena ukuran perusahaan menggambarkan kondisi suatu perusahaan. Firm size juga dapat dinyatakan berdasarkan total aktiva perusahaan (Pasaribu dan Kowanda, 2013). Semakin besar ukuran perusahaan maka semakin meningkat juga nilai perusahaan dikarenakan ukuran perusahaan menentukkan kinerja perusahaan tersebut di mata investor.

Selain itu, perusahaan juga dapat menerapkan kebijakan dividen yang merupakan kebijakan mengenai pembayaran laba perusahaan kepada pemegang saham sesuai dengan jumlah saham yang dimiliki (Senata, 2016). Tujuan melakukan kebijakan dividen untuk meningkatkat penghasilan laba sehingga nilai perusahaan tersebut dapat meningkat. Untuk mengetahui kemampuan perusahaan dalam menghasilkan laba dan memberikan gambaran mengenai efektifitas manajemen dalam menjalankan kegiatan operasional maka digunakan rasio profitabilitas (Wijoyo, 2018).

Penelitian ini mengkaji mengenai pengaruh leverage, business risk, firm size, kebijakan dan profitabilitas terhadap nilai perusahaan pada perusahaan manufaktur sektor consumer goods yang terdaftar di Bursa Efek Indonesia periode 2016-2019. Melihat kemajuan e-commerce di Indonesia yang terus meningkat seiring berjalannya waktu sehingga akan sangat berpengaruh terhadap industri consumer goods karena akan mempermudah pembeli untuk mendapatkan produk yang diinginkan tanpa adanya hambatan jarak dan waktu. Oleh karena itu, penelitian ini menggunakan sampel perusahaan manufaktur sektor consumer goods.

Hasil penelitian ini diharapkan dapat menjadi acuan untuk perusahaan mngenai faktorfaktor yang dapat meningkatkan nilai perusahaan sehingga perusahaan dapat meningkatkan nilai perusahaan untuk mendukung perekonomian Indonesia. Selain itu, hasil penelitian ini juga diharapkan dapat membantu masyarakat dalam melakukan investasi sehingga mengurangi risiko terjadinya kerugian serta menjadi referensi bagi akademisi untuk mengembangkan pengetahuan dan penelitian mengenai nilai perusahaan.

\section{KAJIAN TEORI}

\section{Gambaran Umum Teori}

Teori yang digunakan dalam penelitian ini adalah Trade-Off Theory dan Pecking Order Theory. Trade-off theory merupakan teori yang menjelaskan penggunaan utang pada system pengoperasian perusahaan akan meningkatkan nilai perusahaan, yaitu profitabilitas. Selain itu, penggunaan utang merupakan salah satu sumber pendanaan yang tidak akan berhenti digunakan jika masih sanggup menanggung beban operasional. Sedangkan, pecking order theory menjelaskan bahwa suatu perusahaan yang memiliki tingkat keuntungan yang besar dan kebutuhan yang tinggi untuk melakukan pembiayaan investasi dengan jumlaj pendanaan eksternal yang lebih kecil sehingga dapat meningkatkan aktiva perusahaan dengan pengurungan penggunaan utang (Andrianto dan Wibowo, 2007).

\section{Definisi Konseptual Variabel Nilai perusahaan}

Nilai perusahaan merupakan nilai jual untuk menjalankan suatu perusahaan yang dapat memberikan kepuasan kepada para pemegang saham jika harga saham perusahaan meningkat. Semakin tinggi nilai perusahaan maka semakin baik juga perusahaan tersebut dimata investor karena cenderung investor melihat nilai suatu perusahaan sebelum melakukan investasi. 


\section{Leverage}

Leverage merupakan penggunaan utang yang digunakan suatu perusahaan dengan tujuan untuk mendanai kegiatan operasional perusahaan. Akan tetapi, penggunaan utang harus diperhatikan dan dipertimbangkan baik-baik.

\section{Business risk}

Business risk sendiri adalah risiko yang dihadapi suatu perusahaan jika tidak dapat membiayai biaya operasional perusahaan dan dipengaruhi oleh pendapatan dan biaya yang tidak stabil sehingga tingkat penggunaan utang tinggi.

\section{Firm size}

Firm size diartikan sebagai skala yang menentukan besar kecilnya suatu perusahaan yang dapat dilihat dari total aktiva yang dimiliki perusahaan.

\section{Kebijakan Dividen}

Kebijakan dividen merupakan kebijakan tentang persentase pembagian laba para pemegang saham perusahaan sesuai dengan besarnya jumlah yang akan diterima investor.

\section{Profitabilitas}

Profitabilitas adalah kemampuan perusahaan dengan memperlihatkan hasil kinerja dalam menghasilkan laba perusahaan tersebut. Semakin tinggi nilai progitabilitas maka semakin besar juga laba yang dihasilkan perusahaan dan akan berdampak terhadap peningkatan pengembalian (return) bagi pemegang saham.

\section{Hubungan antara Variabel Leverage dan Nilai Perusahaan}

Perusahaan memutuskan penggunaan utang bertujuan untuk memotong biaya penghasilan pajak karena biaya yang dikeluarkan digunakan untuk pembayaran bunga pinjaman, sehingga dana dapat dialokasikan untuk pembagian dividen maupun untuk melakukan investasi (Suwardika dan Mustanda, 2017). Hal ini mendapat tanggapan positif dari para investor karena investor berekspetasi terhadap perolehan dividen yang besar sehingga meningkatkan permintaan saham di pasar modal dan berdampak pada nilai perusahaan tersebut.

\section{Business Risk dan Nilai Perusahaan}

Berdasarkan trade-off theory yang menyatakan bahwa semakin besar utang maka risiko kebangkrutan yang akan ditanggung oleh perusahaan semakin besar sehingga akan menyebabkan penurunan nilai perusahaan (Saraswathi et al., 2016). Hal ini disebabkan semakin besarnya beban bunga tetap yang harus dibayar sehingga meningkatkan risiko dan kemudian pendapatan yang diperoleh semakin menurun dan berdampak pada risiko yang akan timbul dan berakibat pada nilai perusahaan. Risiko bisnis yang tinggi akan menyebabkan penurunan kemampuan perusahaan dalam memperoleh pinjaman karena perusahaan tidak sanggup dalam menanggung beban tetap dari utang.

\section{Firm Size dan Nilai Perusahaan}

Besar kecilnya ukuran perusahaan berpengaruh terhadap nilai perusahaat tersebut, semakin besar perusahaan tersebut maka semakin besar juga nilai perusahaan tersebut. Selain itu, semakin besar perusahaan maka semakin besar juga kemungkinan utang yang dimilikinya. Penarikan utang dapat membuat perusahan memperoleh aset yang besar pula karena aset jika dijadikan jaminan untuk mendapatkan utang maka nilainya akan lebih besar daripada pengembalian aset yang diterima perusahaan (Rahmawati et al., 2015). 


\section{Kebijakan Dividen dan Nilai Perusahaan}

Kebijakan dividen merupakan kebijakan yang dibuat perusahaan mengenai laba perusahaan tersebut yang akan dibagikan menjadi dividen para pemegang saham. Selain itu bisa juga menjadi laba ditahan perusahaan. Pembagian dividen yang terlalu besar kepada investor dapat berdampak pada harga saham perusahaan itu sendiri (Wijaya dan Sedana, 2015).

\section{Profitabilitas dan Nilai Perusahaan}

Semakin besar laba bersih yang diterima oleh perusahaan, maka semakin baik juga kemampuan suatu perusahaan dalam melakukan pembagian dividen kepada para pemegang saham dan biaya kegiatan operasional perusahaan. Tingkat keuntungan yang tinggi juga memberikan harapan yang baik kepada investor karena dianggap sebagai prospek perusahaan yang baik, dan memberikan dorongan peningkatan permintaan saham perusahaan. Tingginya jumlah dividen yang dibagikan dan meningkatnya permintaan saham perusahaan akan berdampak pada meningkatnya nilai perusahaan (Febrianti, 2012).

\section{Penelitian Relevan}

Suwardika dan Mustanda (2017) menyatakan bahwa leverage dan profitabilitas memiliki pengaruh positif dan signifikan terhadap nilai perusahaan, sedangkan ukuran perusahaan tidak memiliki pengaruh yang signifikan terhadap nilai perusahaan. Penelitian oleh Efni dkk (2011) menjelaskan bahwa kebijakan dividen tidak mempunyai pengaruh yang signifikan terhadap nilai perusahaan jika dimediasi dengan variabel risiko maka mendapatkan hasil bahwa kebijakan deviden juga tidak mempunya pengaruh yang signifikan terhadap risiko perusahaan. Yang terakhir merupakan pengaruh risiko yang hasilnya mempunyai pengaruh yang signifikan dan negatif terhadap nilai perusahaan.

Saraswathi, et al (2016) dalam penelitiannya menyatakan bahwa risiko bisnis dan profitabilitas memiliki pengaruh yang positif dan signifikan terhadap nilai perusahaan. Rahmawati, et al (2015) melalui penelitian ini menjelaskan bahwa profitabilitas berpengaruh positif dan signifikan terhadap nilai perusahaan, sedangkan ukuran perusahaan berpengaruh positif tetapi tidak signifikan terhadap nilai perusahaan. Putra dan Lestari (2016) menjelaskan bahwa kebijakan dividen, profitabilitas, dan ukuran perusahaan berpengaruh positif dan signifikan terhadap nilai perusahaan.

Dalam penelitian yang dilakukan Wijaya dan Sedana (2015) menjelaskan bahwa profitabilitas memiliki pengaruh positif dan signifikan terhadap kebijakan dividen dan nilai perusahaan. Selain itu kebijakan dividen juga memiliki pengaruh yang positif dan signifikan terhadap nilai perusahaan. Febrianti (2012) menyatakan bahwa profitabilitas, ukuran perusahaan, dan leverage memiliki pengaruh positif dan signifikan terhadap nilai perusahaan.

\section{Hipotesis}

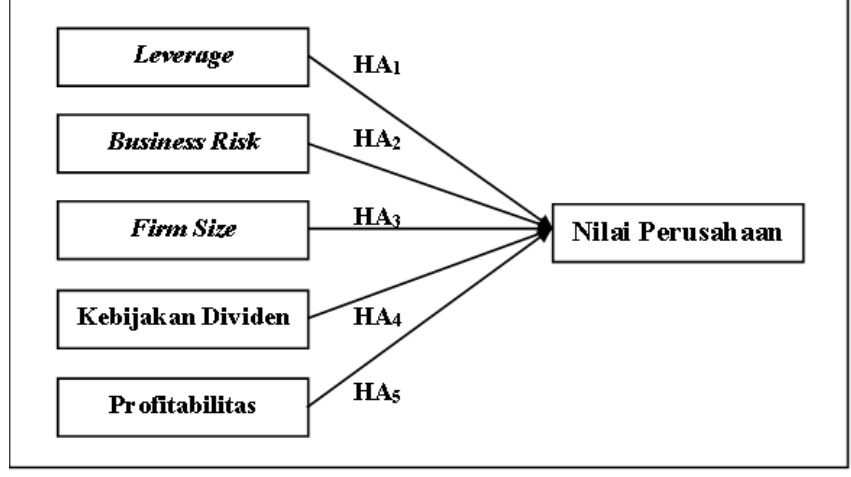

Gambar 1. Kerangka Pemikiran

$\mathrm{HA}_{1}$ : Leverage memiliki pengaruh terhadap nilai perusahaan.

$\mathrm{HA}_{2}$ : Business risk memiliki pengaruh terhadap nilai perusahaan.

$\mathrm{HA}_{3}$ : Firm size memiliki pengaruh terhadap nilai perusahaan. 
$\mathrm{HA}_{4}$ : Kebijakan dividen memiliki pengaruh terhadap nilai perusahaan.

$\mathrm{HA}_{5}$ : Profitabilitas memiliki pengaruh terhadap nilai perusahaan.

\section{METODOLOGI}

Metode yang digunakan dalam penelitian ini adalah metode kuantitatif, dan desain penelitian yang digunakan bersifat deskriptif. Penelitian ini menggunakan data panel (pooled data) yang merupakan gabungan dari data time series dan data cross-section.

Subyek dalam penelitian ini adalah perusahaan manufaktur sektor consumer goods yang terdaftar di Bursa Efek Indonesia periode 2016-2019. Data yang diambil merupakan laporan keuangan tahunan perusahaan dan diperoleh melalui website resmi BEI, yakni www.idx.co.id dan www.idnfinancials.com. Penelitian ini menggunakan teknik dari non-probability sampling yaitu dengan purposive sampling. Dari 58 perusahaan manufaktur sektor consumer goods yang terdaftar di BEI, setelah melalui teknik purposive sampling, jumlah sampel yang memenuhi kriteria dan dapat digunakan dalam penelitian adalah sebanyak 18 perusahaan. Data-data kemudian dikumpulkan ke dalam Microsoft Excel, diolah menggunakan software Eviews 10. Berikut operasionalisiasi dari variabel yang diteliti pada penelitian ini, dimana seluruh operasionalisasi variabel menggunakan skala rasio:

$\begin{array}{ll}\text { Nilai Perusahaan } & : \text { PBV }=\frac{\text { Market Price per Shar }}{\text { Book Value per Share }} \\ \text { Leverage } & : \text { DAR }=\frac{\text { Total Debt }}{\text { Total Assets }} \\ \text { Business Risk } & : \text { DAR }=\frac{\text { Total Debt }}{\text { Total Assets }} \\ \text { Firm Size } & : \text { SIZE }=\text { Ln Total Assets } \\ \text { Kebijakan Dividen } & : \text { DPR }=\frac{\text { Dividend per Share }}{\text { Earnings per Share }} \\ \text { Profitabilitas } & : \text { ROE }=\frac{\text { Net Income }}{\text { Total Equity }}\end{array}$

\section{HASIL ANALISIS DATA}

Tabel 1. Hasil Uji Multikolinearitas

\begin{tabular}{|c|c|c|c|c|c|}
\hline & DAR & DOL & SIZE & DPR & ROE \\
\hline DAR & 1.000000 & -0.082319 & 0.341931 & -0.409313 & -0.225598 \\
DOL & -0.082319 & 1.000000 & -0.245677 & -0.184691 & -0.229915 \\
SIZE & 0.341931 & -0.245677 & 1.000000 & 0.134105 & 0.408860 \\
DPR & -0.409313 & -0.184691 & 0.134105 & 1.000000 & 0.653518 \\
ROE & -0.225598 & -0.229915 & 0.408860 & 0.653518 & 1.000000 \\
\hline
\end{tabular}

Berdasarkan Tabel 1 dapat dijelaskan bahwa variabel-variabel independen memiliki nilai korelasi yang tidak melebihi 0,8. Maka dapat disimpulkan bahwa tidak terjadi multikolinearitas antar variabel-variabel independen yang terdapat pada penelitian ini terhadap perusahaan manufaktur sektor consumer goods yang terdaftar di Bursa Efek Indonesia periode 2016-2019.

Tabel 2. Hasil Statistik Deskriptif

\begin{tabular}{|l|c|c|c|c|c|c|}
\hline & PBV & DAR & DOL & SIZE & DPR & ROE \\
\hline Mean & 3.220593 & 0.334218 & 3.553408 & 29.57564 & 0.419611 & 0.153190 \\
Median & 2.003737 & 0.303705 & 1.579862 & 29.39228 & 0.400225 & 0.155846 \\
Maximum & 16.12848 & 0.728454 & 53.67315 & 32.20096 & 1.132701 & 0.384574 \\
\hline
\end{tabular}




\begin{tabular}{|l|c|c|c|c|c|c|} 
Minimum & 0.294542 & 0.076894 & -10.01407 & 26.71307 & 0.000000 & 0.002144 \\
Std. Dev. & 2.948060 & 0.173097 & 8.769764 & 1.466041 & 0.286660 & 0.086021 \\
Skewness & 2.108917 & 0.659252 & 4.165829 & 0.124034 & 0.511607 & 0.690691 \\
Kurtosis & 8.616769 & 2.389019 & 22.30898 & 2.069914 & 2.710525 & 3.562565 \\
& & & & & & \\
Jarque-Bera & 148.0147 & 6.335251 & 1326.760 & 2.779794 & 3.392283 & 6.674082 \\
Probability & 0.000000 & 0.042103 & 0.000000 & 0.249101 & 0.183390 & 0.035542 \\
& & & & & & \\
Sum & 231.8827 & 24.06370 & 255.8454 & 2129.446 & 30.21196 & 11.02966 \\
Sum Sq. Dev. & 617.0652 & 2.127353 & 5460.522 & 152.5987 & 5.834337 & 0.525371 \\
& & & & & & \\
Observations & 72 & 72 & 72 & 72 & 72 & 72 \\
\hline
\end{tabular}

Berdasarkan Tabel 2 dapat dijelaskan bahwa PBV merupakan variabel dependen dan DAR, DOL, SIZE, DPR, dan ROE merupakan variabel independen penelitian. Pada tabel tersebut, nilai minimum kebijakan dividen bernilai 0 karena terdapat perusahaan yang tidak melakukan pembagian dividen pada suatu tahun dalam periode penelitian ini.

Tabel 3. Hasil Uji-F

\begin{tabular}{|llll|}
\hline \hline \multicolumn{4}{|c|}{ Effects Specification } \\
\hline \hline Cross-section fixed (dummy variables) & & \\
\hline \hline R-squared & 0.914279 & Mean dependent var & 3.220593 \\
Adjusted R-squared & 0.875791 & S.D. dependent var & 2.948060 \\
S.E. of regression & 1.038992 & Akaike info criterion & 3.168422 \\
Sum squared resid & 52.89572 & Schwarz criterion & 3.895691 \\
Log likelihood & -91.06320 & Hannan-Quinn criter. & 3.457950 \\
F-statistic & 23.75541 & Durbin-Watson stat & 1.880082 \\
\cline { 1 - 2 } Prob(F-statistic) & 0.000000 & & \\
\hline \hline
\end{tabular}

Berdasarkan Tabel 3 dapat dijelaskan bahwa nilai probabilitas dari $F$-statistic penelitian ini sebesar 0,000000 yang berarti nilai probabilitas tersebut lebih kecil dari $0,05(<0,05)$. Sehingga dapat diartikan bahwa leverage (DAR), business risk (DOL), firm size (SIZE), kebijakan dividen (DPR), dan profitabilitas (ROE) secara simultan mampu memberikan pengaruh yang signifikan terhadap nilai perusahaan (PBV).

Tabel 4. Hasil Uji-T

\begin{tabular}{|c|r|r|r|l|}
\hline Variable & Coefficient & Std. Error & t-Statistic & Prob. \\
\hline C & 60.77030 & 27.15641 & 2.237788 & 0.0298 \\
DAR & -13.29256 & 6.480684 & -2.051104 & 0.0456 \\
DOL & 0.002964 & 0.015873 & 0.186761 & 0.8526 \\
SIZE & -1.879135 & 0.935225 & -2.009287 & 0.0500 \\
DPR & 1.108855 & 1.033553 & 1.072858 & 0.2886 \\
ROE & 13.01458 & 5.405282 & 2.407752 & 0.0199 \\
\hline
\end{tabular}

Berdasarkan Tabel 4 dapat dijelaskan bahwa nilai probabilitas signifikansi variabel independen leverage adalah sebesar 0,0456, atau lebih kecil dari 0,05. Maka artinya adalah terdapat pengaruh signifikan antara leverage terhadap nilai perusahaan. Nilai probabilitas signifikansi variabel independen business risk adalah sebesar 0,8526, atau lebih besar dari 0,05. Maka artinya adalah tidak terdapat pengaruh signifikan antara business risk terhadap nilai perusahaan. Nilai probabilitas signifikansi variabel independen firm size adalah sebesar 0,0500, atau lebih kecil sama dengan 0,05. Maka artinya adalah terdapat pengaruh signifikan antara firm size terhadap nilai perusahaan. Nilai probabilitas signifikansi variabel independen kebijakan 
dividen adalah sebesar 0,2886, atau lebih besar dari 0,05. Maka artinya adalah tidak terdapat pengaruh signifikan antara kebijakan dividen terhadap nilai perusahaan. Nilai probabilitas signifikansi variabel independen profitabilitas adalah sebesar 0,0199, atau lebih kecil dari 0,05. Maka artinya adalah terdapat pengaruh yang signifikan antara profitabilitas terhadap nilai perusahaan.

\section{Hasil Uji Koefisien Determinasi $\left(\mathbf{R}^{2}\right)$}

Tabel 5. Hasil Uji Koefisien Determinasi

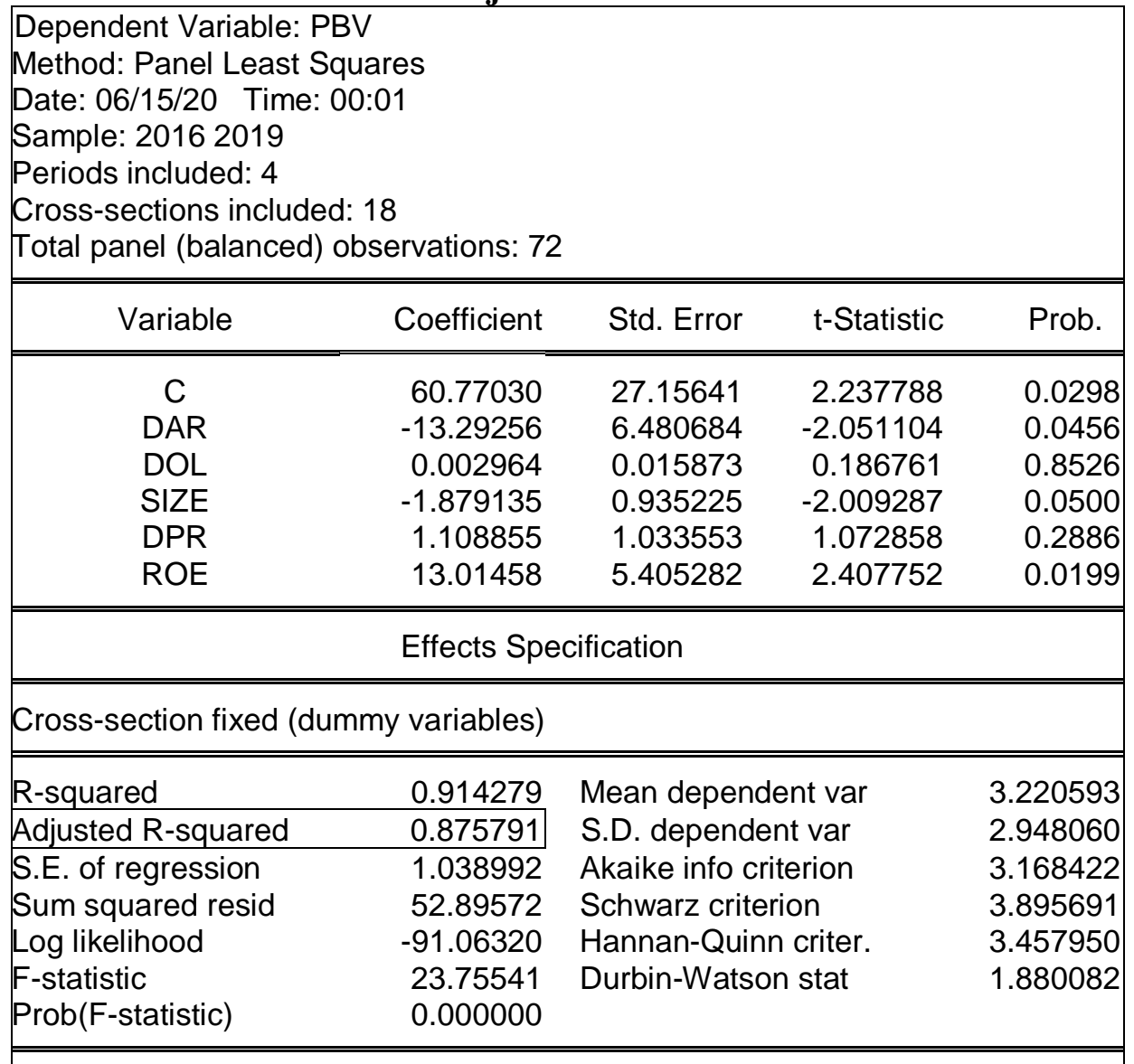

Berdasarkan Tabel 5 dapat dijelaskan bahwa nilai dari Adjusted $R$-squared adalah sebesar 0,875791 atau $87,58 \%$. Oleh karena itu, variabel nilai perusahaan (PBV) sebesar 87,58\% dapat dijelaskan oleh variabel leverage (DAR), business risk (DOL), firm size (SIZE), kebijakan dividen (DPR), dan profitabilitas (ROE). Sisanya sebesar 12,42\% dapat dijelaskan oleh variabel lain di luar dari variabel independen pada penelitian ini.

\section{DISKUSI}

\section{Pengaruh Leverage terhadap Nilai Perusahaan}

Hasil penelitian ini menunjukkan bahwa leverage memiliki pengaruh yang negatif dan signifikan terhadap nilai perusahaan pada perusahaan manufaktur sektor consumer goods yang terdaftar di Bursa Efek Indonesia periode 2016-2019. Hal ini berarti jika nilai leverage naik, maka nilai perusahaan akan menurun, dan juga sebaliknya. Hasil penelitian ini konsisten dengan penelitian yang dilakukan Sari (2016) dan juga Sari dan Abundanti (2014) yang menyatakan bahwa leverage memiliki pengaruh yang negatif dan signifikan terhadap nilai perusahaan. Selain itu, hal ini juga selaras dengan trade-off theory yang menyatakan bahwa jumlah utang yang 
semakin meningkat (berlebihan) dapat menurunkan nilai perusahaan. Namun, penelitian ini bertolak belakang dengan Ernawati dan Widyawati (2015) yang menyatakan bahwa leverage tidak memiliki pengaruh terhadap nilai perusahaan.

\section{Pengaruh Business Risk terhadap Nilai Perusahaan}

Hasil penelitian ini menunjukkan bahwa business risk tidak memiliki pengaruh signifikan terhadap nilai perusahaan pada perusahaan manufaktur sektor consumer goods yang terdaftar di Bursa Efek Indonesia periode 2016-2019. Hasil penelitian ini konsisten dengan penelitian yang dilakukan Sari dan Wijayanto (2015) dan Handayani dkk (2014) yang menyatakan bahwa business risk tidak memiliki pengaruh yang signifikan terhadap nilai perusahaan. Hasil seperti ini dapat disebabkan oleh banyaknya variasi data nilai business risk sehingga memungkinkan terjadinya ketidak-signifikan antar variabel business risk dengan nilai perusahaan. Namun, penelitian ini bertolak belakang dengan Saraswathi, et al (2016) yang menyatakan bahwa business risk memiliki pengaruh yang positif dan signifikan terhadap nilai perusahaan.

\section{Pengaruh Firm Size terhadap Nilai Perusahaan}

Hasil penelitian ini menunjukkan bahwa firm size memiliki pengaruh yang negatif dan signifikan terhadap nilai perusahaan pada perusahaan manufaktur sektor consumer goods yang terdaftar di Bursa Efek Indonesia periode 2016-2019. Hal ini berarti jika nilai firm size naik, maka nilai perusahaan akan menurun, dan juga sebaliknya. Hal ini terjadi dikarenakan semakin besar jumlah aset akan menurunkan nilai perusahaan yang disebabkan oleh perputaran aset yang lama. Hasil penelitian ini konsisten dengan penelitian yang dilakukan Prastuti dan Sudiartha (2016) dan Wiyono (2012) yang menyatakan bahwa ukuran perusahaan berpengaruh negatif dan signifikan terhadap nilai perusahaan. Namun, penelitian ini bertolak belakang dengan Suwardika dan Mustanda (2017) yang menyatakan bahwa ukuran perusahaan memiliki pengaruh yang tidak signifikan dikarenakan perusahaan tidak dapat diliat berdasarkan ukuran perusahaan saja melainkan aspek-aspek lain seperti kinerja perusahaan dan laporan keuangan.

\section{Pengaruh Kebijakan Dividen terhadap Nilai Perusahaan}

Hasil penelitian ini menunjukkan bahwa kebijakan dividen tidak memiliki pengaruh yang signifikan terhadap nilai perusahaan pada perusahaan manufaktur sektor consumer goods yang terdaftar di Bursa Efek Indonesia periode 2016-2019. Hasil penelitian ini konsisten dengan penelitian yang dilakukan Efni dkk (2011) dan Wijoyo (2018) yang menyatakan bahwa kebijakan dividen tidak memiliki pengaruh yang signifikan terhadap nilai perusahaan. Namun, hasil penelitian ini bertolak belakang dengan penelitian Putra dan Lestari (2016) serta Novita (2014) yang menyatakan bahwa kebijakan dividen memiliki pengaruh yang positif dan signifikan terhadap nilai perusahaan karena pembagian dividen oleh perusahaan dapat menarik minat para investor untuk melakukan investasi.

\section{Pengaruh Profitabilitas terhadap Nilai Perusahaan}

Hasil penelitian ini menunjukkan bahwa profitabilitas memiliki pengaruh yang positif dan signifikan terhadap nilai perusahaan pada perusahaan manufaktur sektor consumer goods yang terdaftar di Bursa Efek Indonesia periode 2016-2019. Hal ini berarti jika nilai profitabilitas naik, maka nilai perusahaan akan meningkat, dan juga sebaliknya. Hasil penelitian ini konsisten dengan penelitian yang dilakukan Suwardika dan Mustanda (2017), Putra dan Lestari (2016) serta Wijaya dan Sedana (2015) yang menyatakan bahwa profitabilitas memiliki pengaruh yang positif dan signifikan terhadap nilai perusahaan. 


\section{PENUTUP}

Penelitian ini tentunya memiliki beberapa keterbatasan, diantaranya yaitu subyek penelitian yang hanya terdiri dari perusahaan-perusahaan manufaktur sektor consumer goods yang terdaftar di Bursa Efek Indonesia. Rentang waktu yang digunakan untuk subyek penelitian hanya selama 4 tahun, yaitu tahun 2016 sampai dengan 2019. Maka dari itu beberapa saran yang dapat diberikan adalah perusahaan manufaktur sektor consumer goods sebaiknya memperhatikan faktor-faktor leverage, firm size, dan profitabilitas karena dalam penelitian ini terbukti memiliki pengaruh yang signifikan terhadap nilai perusahaan. Penelitian berikutnya disarankan untuk menggunakan subyek penelitian perusahaan manufaktur sektor consumer goods beserta basic industry and chemicals, dan miscellaneous industry atau perusahaan yang bergerak di industri lain, seperti perusahaan perbankan, jasa, dan lainya. Penelitian selanjutnya juga disarankan untuk memperpanjang rentang untuk sampel penelitian, tidak hanya terbatas pada 4 tahun saja. Penelitian selanjutnya disarankan untuk menambah variabel independen lain yang dianggap dapat menjadi salah satu faktor yang dapat memberikan pengaruh terhadap nilai perusahaan, seperti struktur modal, likuiditas, firm growth, dan variabel pengukur lainnya dengan tujuan untuk melihat apakah ada variabel lain yang harus diperhatikan untuk memaksimalkan nilai perusahaan.

\section{DAFTAR PUSTAKA}

Adrianto dan Wibowo, B. (2007). Pengujian Teori Pecking Order Pada Perusahaanperusahaan Non Keuangan LQ45 Periode 2001-2005. Manajemen Usahawan Indonesia, XXXVI, volume 12, hal. 45-53.

Efni, Yulia., et al. 2011. Keputusan Investasi, Keputusan Pendanaan, dan Kebijakan Deviden: Pengaruhnya terhadap Nilai Perusahaan (Studi pada Sektor Properti dan Real Estate di Bursa Efek Indonesia). Jurnal Aplikasi Manajemen, Vol. 10, No. 1. ISSN: 1693-5241.

Ernawati, D., \& Widyawati, D. (2015). Pengaruh Profitabilitas, Leverage dan Ukuran Perusahaan terhadap Nilai Perusahaan. Jurnal Ilmu \& Riset Akuntansi, IV(4).

Febrianti, M. (2012). Faktor-Faktor yang Mempengaruhi Nilai Perusahaan pada Industri Pertambangan di Bursa Efek Indonesia. Jurnal Bisnis dan Akuntansi, XIV(2), 141-156.

Handayani, Meitri., Yulia Efni, dan Ahmad Fauzan Fathoni. 2014. Pengaruh Keputusan Investasi dan Keputusan Pendanaan yang Dimediasi Oleh Risiko Terhadap Nilai Perusahaan (Studi Pada Perusahaan Manufaktur Sektor Aneka Industri Periode 20082012). Dalam JOM FEKON VOL. 1 NO. 2 OKTOBER 2014, Tahun 2014, Halaman 115. Pekanbaru : Universitas Riau.

Keown. 2004. Manajemen Keuangan : Prinsip-Prinsip dan Aplikasi. Edisi 9, Indeks. Jakarta.

Novita Sartini, Luh Putu dan Ida Bagus Anom Purbawangsa. 2014. Pengaruh Keputusan Investasi, Kebijakan Dividen, serta Keputusan Pendanaan Terhadap Nilai Perusahaan Manufaktur di Bursa Efek Indonesia. Jurnal Manajemen. Fakultas Ekonomi Universitas Udayana

Pasaribu, R. B., \& Kowanda, D. (2013). Kesempatan Investasi dan Determinan Kebijakan Pendanaan Perusahaan Publik Indonesia. Jurnal Akuntansi Akrual, 5.

Prastuti, Rai Kadek Ni dan I Gede Merta Sudiartha. 2016. Pengaruh Struktur Modal, Kebijakan Deviden, dan Ukuran Perusahaan terhadap Nilai Perusahaan. E- Jurnal Manajemen Unud.

Purwohandoko. (2017). The Influence of Firm's Size, Growth, and Profitability on Firm Value with Capital Structure as the Mediator: A Study on the Agricultural Firms Listed in the Indonesian Stock Exchange. International Journal of Economics and Finance, IX(8), 103-110. 
Putra, A. N., \& Lestari, P. V. (2016). Pengaruh Kebijakan Dividen, Likuiditas, Profitabilitas dan Ukuran Perusahaan terhadap Nilai Perusahaan. E-Jurnal Manajemen Unud, V(7), 40444070.

Rahmawati, Amalia Dewi., Topowijono. Sulasmiyati, Sri. 2015. Pengaruh Ukuran Perusahaan, Profitabilitas, Struktur Modal, dan Keputusan Investasi terhadap Nilai Perusahaan (Studi pada Perusahaan pada Sektor Properti, Real Estate, dan Building Construction yang terdaftar di BEI periode 2010-2013). Jurnal Administrasi Bisnis, Vol.23, No. 2.

Saraswathi, IAA., Wiksuana, IGB.,dan Rahyuda, H. (2016). Pengaruh Risiko Bisnis, Pertumbuhan Perusahaan Dan Struktur Modal Terhadap Profitabilitas Serta Nilai Perusahaan Manufaktur. E-Jurnal Ekonomi dan Bisnis Universitas Udayana. ISSN: 2337-3067 Hal. 1729-1756.

Sari, Evrila Lupita dan Andhi Wijayanto. 2015. Pengaruh Keputusan Investasi, Pendanaan, dan Dividen terhadap Nilai Perusahaan dengan Risiko sebagai Variabel Mediasi. Management Analysis Journal. Volume 4. Nomor 4. Semarang : Universitas Negeri Semarang.

Sari, P. I., \& Abundanti, N. (2014). Pengaruh Pertumbuhan Perusahaan dan Leverage terhadap Profitabilitas dan Nilai Perusahaan. Journal Management of Finance, 1427-1441.

Sari, R. A. I., \& Priyadi, M. P. (2016). Pengaruh Leverage, Profitabilitas, Size , Dan Growth Opportunity Terhadap Nilai Perusahaan. Jurnal Ilmu Dan Riset Manajemen, 5(10), 2 17.

Senata, M. (2016). Pengaruh Kebijakan Dividen terhadap Nilai Perusahaan yang Tercatat pada Indeks LQ-45 Bursa Efek Indonesia. Jurnal Wira Ekonomi Mikroskil, VI(1), 73-84.

Suwardika, I. N., \& Mustanda, I. K. (2017). Pengaruh Leverage, Ukuran Perusahaan, Pertumbuhan Perusahaan, dan Profitabilitas terhadap Nilai Perusahaan pada Perusahaan Propoerti. E-Jurnal Manajemen Unud, VI(3), 1248-1277.

Wijaya, B. I., \& Sedana, L. P. (2015). Pengaruh Profitabilitas Terhadap Nilai Perusahaan (Kebijakan Dividen dan Kesempatan Investasi Sebagai Variabel Mediasi). E-Jurnal Manajemen Unud, IV(12), 4477-4500.

Wijoyo, A. (2018). Faktor-Faktor yang Mempengaruhi Nilai Perusahaan pada Perusahaan Property dan Real Estate di Bursa Efek Indonesia. Jurnal Ekonomi, XXIII(1), 48-61.

Wiyono, Lany Indriana. 2012. Pengaruh Struktur Kepemilikan, Kebijakan Dividen Dan Ukuran Perusahaan Terhadap Nilai Perusahaan Pada Industri Manufaktur Yang Terdaftar Di BEI Periode 2009-2011. Jurnal Fakultas Bisnis Universitas Katolik Widya Mandala, Surabaya. 